\title{
THE CONTRIBUTION OF STUDENTS' ATTITUDE AND FAMILIARITY DEGREE ON ENGLISH LOANWORDS IN BAHASA INDONESIA TOWARD THEIR ENGLISH VOCABULARY MASTERY
}

\author{
Syahrul \\ Fakultas Tarbiyah \& IImu Keguruan (FTIK) IAIN Bukittinggi \\ JI. Gurun Aur Kabupaten Agam Sumatera Barat, 26134, Indonesia \\ Email:syah09shabry@gmail.com
}

\begin{abstract}
The research is aimed to determine the contribution of Information Technology (IT) students' attitude and level of familiarity in using English loanwords in bahasa Indonesia toward their English vocabulary mastery. The type of research was a correlational study of contribution. The research population was the fifth-semester students of IT in the academic year 2018/2019 at IAIN Bukittinggi with the total number of population was 180 students. The sample selection was done by using cluster random sampling technique with the total of the sample was 45 students from 6 parallel classes. The research data were obtained from attitude questionnaires, familiarity level questionnaires, and English vocabulary test. These instruments were analyzed statistically by using simple and multiple regression with a significance level was 0.05 . Based on the data analysis, it was obtained the equation of $Y=$ $4.192+0.227 X_{1}+0.5 X_{2}$ that was indicated a positive contribution of students' attitude and familiarity degree on English loanwords toward their English vocabulary mastery. Due to the value of $F$ change $(0.00)$ was lower than $\alpha=0.05$, means that the variables of $X_{1}$ and $X_{2}$ contributed significantly toward the variable of $Y$ (the students' English vocabulary mastery). Then, the coefficient of determination $R^{2}$ was 0.468 indicated variables $X_{1}$ and $X_{2}$ gave contribution simultaneously as much as $46.8 \%$ toward variable $\mathrm{Y}$, while as much as $63.2 \%$ was affected by other factors. So, the existence of English loanwords in Bahasa Indonesia gives a potential opportunity to make English is easy to be learned. Because both between loanwords and English vocabularies have similarities in form and meaning. So, in order to give a meaningful, positive attitude and familiarity degree of loanwords must be developed.
\end{abstract}

Keywords: loanwords, attitude, familiarity degree, and vocabulary mastery

\section{KONTRIBUSI SIKAP DAN TINGKAT FAMILIARITAS MAHASISWA PADA KOSAKATA SERAPAN BAHASA INGGRIS DALAM BAHASA INDONESIA TERHADAP PENGUASAAN KOSAKATA BAHASA INGGRIS}

\begin{abstract}
Abstrak
Penelitian ini bertujuan untuk mengetahui kontribusi sikap dan tingkat familiaritas mahasiswa teknologi Informatika IAIN Bukittinggi dalam menggunakan kosakata serapan bahasa Inggris yang ada di dalam Bahasa Indonesia terhadap penguasaan kosakata bahasa Inggris mereka. Penelitian ini bertipe korelasi dalam bentuk kontribusi.
\end{abstract}


Populasi penelitian ini adalah mahasiswa IAIN Bukittinggi semester $\mathrm{V}$ tahun ajaran 2018/2019 yang berjumlah 180 orang. Pemilihan sampel dilakukan dengan cara cluster random sampling. Jumlah sampel adalah 45 mahasiswa dari $6 \mathrm{kel}$ as paralel. Data penelitian diperoleh dari angket sikap, angket tingkat familiaritas penggunaan kosakata serapan Bahasa Inggris, dan tes penguasaan kosakata bahasa Inggris. Teknik analisis statistik yang digunakan adalah regresi dan korelasi sederhana dan ganda melalui korelasi Product Moment dengan taraf signifikansi 0,05. Dari analisa data, diperoleh garis persamaan $Y=4.192+0.227 X 1+0.5 X 2$, dimana menunjukkan terdapat kontribusi positif dari sikap dan tingkat familiaritas mahasiswa pada Kosakata serapan Bahasa Inggris dalam Bahasa Indonesia terhadap penguasaan Bahasa Inggris. Nilai $F$ change $(0.00)$ lebih kecil dari $\alpha=0.05$, artinya $X_{1}$ dan $X_{2}$ berkontribusi secara signifikan terhadap variable $Y$ (penguasaan kosakata Bahasa Inggris). Kemudian dari nilai koefisien determinasi $\mathrm{R}^{2}$ sebesar 0.486 , dapat dimaknai bahwa sumbangan $\mathrm{X}_{1}$ dan $\mathrm{X}_{2}$ secara bersamaan pada Variabel $Y$ sebesar $48,6 \%$ dan sisanya sebesar $63,4 \%$ ditentukan oleh faktor lain. Jadi keberadaan kosakata serapan Bahasa Inggris dan Bahasa Indonesia memiliki potensi untuk memudahkan dan meringankan beban pembelajaran kosakata Bahasa Inggris itu sendiri. Karena kata serapan dan kosakata bahasa Inggris memiliki kemiripan atau bahkan kesamaan pada segi ejaan dan arti. Agar memberikan manfaat, maka sikap positif dan tingkat familiaritas terhadap kosakata Serapan Bahasa Inggris perlu ditumbuhkembangkan.

Kata kunci: kosakata serapan, sikap, tingkat familiaritas, dan penguasaan kosakata

\section{A. Introduction}

Mastery of English vocabulary is not easy for most learners, especially for students in Indonesia where English is learned as a foreign language. There are various ways to learn vocabulary. In general, it is classified into two main strains: intentional and incidental vocabulary learning (Nation, 2001: 369). Thus still encounter a lot of problem e.g. spelling, the difference of pronunciation, meaning and some others. In order to help and make easy the burden of the learners in learning the foreign vocabulary i.e. English, Nation (1987: 205-209) offers the idea about the loanwords role in the mother tongue or first language. He describes that the existence of loanwords in the first language help and make easy the learners' burden in learning vocabulary because loanwords tend to have the similarity or even the sameness in the form, meaning and the way to pronounce it with the vocabulary of language where they derived from.

Due to the characteristics of English loanwords, Nurweni (2013) in her research concluded that most of English loanwords in Bahasa Indonesia have the sameness in meaning and spelling. Other research that was held by Fauzi (2014) showed that many vocabularies in Bahasa Indonesia that are derived from English were the same orthographically. 
Loanwords are words from one language which are incorporated into another. Then, in the process of adopting, words are usually adapted to fit the sound system of the user (Richard \& Schmidt, 2002:56). Loanwords as the process of linguistic have occurred in nearly every speech community in the world since it is the easiest and the most frequent way to fill the absence of a word for one concept in a language or to show the prestige of the user in language.

In fact, several researchers have demonstrated and proved that English loanwords in the mother tongue help learners in studying English in order to recognize, infer, and produce English words. English derived from loanwords gave a positive effect to increase and master the vocabulary of the language that is learned. Yoshida (1978) in his research found that English loanwords in Japan helped Japanese children who live in the United States in learning English words more quickly at their nursery school because of the word similarity. Then, Brown \& Williams (1985) found that EFL students understand the word better if it is a loanword. Meanwhile, Hara (2011) did research about the use of loanwords for learning English vocabulary. He found that loanwords encourage and aid the students to have English vocabulary easier. Loanwords are helpful tools because about two-thirds of those words in the target word of the study had the same meaning as the corresponding word in English. Although Japanese use Katakana (Japanese alphabet, known roman script) that is different from English, the researches about using loanwords in Japanese showed the advantages and lightness in learning the vocabulary of the adopted language.

In Bahasa Indonesia, English Loanwords are abundant. There has been an increasingly significant need to use them. Bahasa Indonesia has absorbed less than 2000 words in many fields, such as in the terms of economics, science, technology and many others. Almost level of community, from common people to scientists, used these vocabularies (Devianty: 2016).

As the educated and academic society, the students in the university like in IAIN Bukittinggi often use, listen and read these vocabularies. Loanwords are often involved consciously or unconsciously when they are discussing in or out 
the classroom, reading books, magazines, and newspapers, or watching TV and listening to news or lectures. Almost nothing of their activities without the presence of the English loanwords. They have been familiar with English Loanwords in Bahasa Indonesia.

Besides, most of the students showed their attitude such as tendency and preference for the use of English loanwords. They preferred to use English Loanwords than Bahasa Indonesia. It was easier for them to say and express their sorrow such as 'sorry' than "Maaf" or used the word "Prediksi" than "Perkiraan". They were using and choosing those vocabularies unconsciously or without awareness. They knew and understood that both are similar or even have the same meaning.

Marzano (1997:3), Ellis (1999:200) and Nation (1987: 119) state that learning a foreign language, and the successful to master their vocabularies are influenced by several aspects i.e. attitude, knowledge, awareness, and familiarity. Vocabulary mastery is regarded as the peak and the result of vocabulary learning.

The existence of English loanword in Bahasa Indonesia is potential to help, lighten and increase the English vocabulary mastery of the students in IAIN Bukittinggi. But the successful in using this potency in order to master English vocabulary might be obstacle by some factors, such as: a) attitude that is indicated by their tendency, preference and likeness to use loanwords; b) familiarity that is indicated by the frequency of contact (see, hear and use) with English loanwords; c) knowledge that is indicated by their ability to use English loanword in Bahasa Indonesia in their daily activities, and d) unawareness that is indicated by their habit in choosing and using the English loanwords spontaneously.

Based on the previous background, this research had purposes to determine: 1) The degree of contribution of students' attitudes on English Loan Words in Bahasa Indonesia toward their English Vocabulary mastery; 2) The degree of contribution of students' familiarity degree on English loanwords in Bahasa Indonesian toward their English Vocabulary mastery; and 3) The degree of 
contribution of students' attitude and familiarity degree on English Loan Words in Bahasa Indonesian toward their English Vocabulary mastery.

\section{B. Research Method}

The type of research is a correlational study with the type of contribution. Correlation is the procedure in quantitative research in which the researcher measures the degree of relationship between two or more variables by using the statistical procedure of correlational analysis. This degree is expressed in the form of a number that is indicated whether the two variables are related or whether one can predict another. The strength of the relationship between variables are expressed in terms of the correlation coefficient, and there is no attempt to control and manipulate the variable like in experimental research (Creswell, 2002: 337-338).

The population of this research was the fifth-semester students of Technology Information Program in IAIN Bukittinggi, the academic year 2018/2019 that is consists of 180 students from six classes. The sample of the research was selected by cluster random sampling and there were 45 students (by getting $25 \%$ of the population). The data of the research were collected through administrating the two kinds of questionnaires i.e. the questionnaire of attitude and familiarity degree on the use of English Loanword in Bahasa Indonesia, and one vocabulary test to get the data of students' English vocabulary mastery that was derived from English loanword in Bahasa Indonesia. Before conducting the administrating of the questionnaire result, Those instruments were tried out and validated by using Pearson's product-moment.

To get the data of students' attitudes, the researcher administered the fivepoint Likert-type attitude scale. The scale contained the statements under the group of three attitude components as follow:

1. Cognitive/informational component: belief, opinion, and prediction, (what someone thinks or predicts about the object).

2. Affective component: like, proud, happy, hate and others (what someone feels about the object). 
3. Conative/ behavioral component: tendency or willingness to act (what someone wants to do against the object).

The questionnaire contained positive and negative statements in the fivepoint scales with the response are: "Strongly agree", "agree" "undecided", "disagree" and "strongly disagree". The data got from the questionnaire were ordinal. To make inline about the result, the requirement was needed to do with parametric statistical analysis. The data were converted from ordinal data to interval one by using MSI (method of a successive interval).

To measure the students' familiarity degree on English loanwords in Bahasa Indonesia, the researcher used the modification of D'Anna's scale (1991:117) research about "Toward a meaningful definition of vocabulary size." The questionnaire of a familiarity degree was administered in five options to respond.

Table 1. A Score of Familiarity Degree

\begin{tabular}{clc}
\hline Category & \multicolumn{1}{c}{ Option } & Score \\
\hline I & I have never seen or heard the word in Bahasa Indonesia & 1 \\
\hline II & $\begin{array}{l}\text { I have seen or heard the word before but I do not know } \\
\text { the meaning in Bahasa Indonesia }\end{array}$ & 2 \\
\hline III & $\begin{array}{l}\text { I have either seen or heard the word before and have a } \\
\text { vague idea of its meaning in Bahasa Indonesia }\end{array}$ & 3 \\
\hline & $\begin{array}{l}\text { I would be able to recognize the meaning of the word if } \\
\text { given the word in a multiple-choice test which included the } \\
\text { IV } \\
\text { correct meaning and several incorrect meanings in Bahasa } \\
\text { Indonesia }\end{array}$ & 4 \\
\hline V & $\begin{array}{l}\text { I know the meaning of the word well enough to give its } \\
\text { definition In Bahasa Indonesia }\end{array}$ & 5 \\
\hline
\end{tabular}

Moreover, to find out the data of students' vocabulary mastery, the researcher used a vocabulary test that indicates the level of students' English vocabulary mastery that was derived from English loanwords in Bahasa Indonesia. The test involved three aspects of vocabulary knowledge. 
Table 2. Scoring Rubric for Vocabulary Knowledge

\begin{tabular}{|c|c|}
\hline Aspect of Vocabulary & Indicator and Testing Format \\
\hline \multirow[t]{3}{*}{ Form } & $\begin{array}{l}\text { Be able to restore English Loanword in Bahasa Indonesia } \\
\text { into a correct English spelling }\end{array}$ \\
\hline & $\begin{array}{l}\text { Returning English loanwords in Bahasa Indonesia into an } \\
\text { English Vocabulary }\end{array}$ \\
\hline & Example: Eksit $\rightarrow$ exit \\
\hline Meaning & $\begin{array}{l}\text { Be able to write the equivalent word in Bahasa Indonesia } \\
\text { Writing the synonym of English Loanword in Bahasa } \\
\text { Indonesia Example: Eksit = keluar }\end{array}$ \\
\hline Use & $\begin{array}{l}\text { Be able to use the word in the right context } \\
\text { Creating a good sentence by using the given English } \\
\text { vocabulary (returned from English loanwords) }\end{array}$ \\
\hline
\end{tabular}

The target words in this research were the loanwords under the categories: a) they have got adaptation to fit the Indonesian spelling and sound system, and have a synonym in Bahasa Indonesia; b) they were included in academic vocabularies (issued by Jim Burke, 2005); and c) they were high frequency often used, heard and seen by the students. The target words can be described in the Venn diagram as follows:

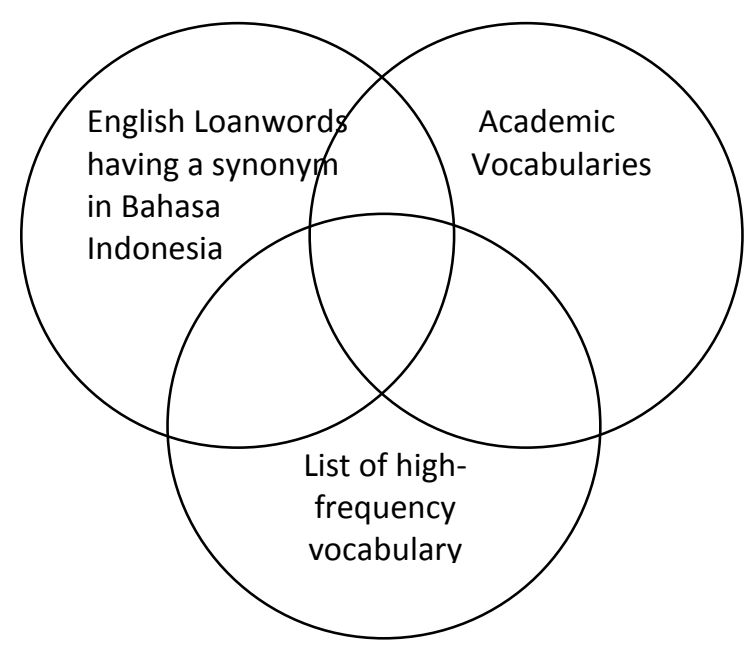

Figure 1. Venn Diagram for Target Words

By having these three filters, the target words which were involved in this research were 115 . 


\section{Research Results and Discussion}

\section{Research Results}

The data of students' attitude, degree of familiarity on English loanwords in Bahasa Indonesia and their English Vocabulary mastery were analyzed by using SPSS 15. The result is shown in the following table:

Table 3. Degree of Familiarity

\begin{tabular}{|c|c|c|c|c|}
\hline \multicolumn{5}{|c|}{ Statistics } \\
\hline & & Attitude & $\begin{array}{c}\text { Familiarity } \\
\text { Degree }\end{array}$ & $\begin{array}{l}\text { Vocab. } \\
\text { Mastery }\end{array}$ \\
\hline \multirow[t]{2}{*}{$\bar{N}$} & Valid & 45 & 45 & 45 \\
\hline & Mis sing & 0 & 0 & 0 \\
\hline \multicolumn{2}{|c|}{ Mean } & 73,9111 & 108,0444 & 26,3333 \\
\hline \multicolumn{2}{|c|}{ Median } & 75,0000 & 109,0000 & 27,0000 \\
\hline \multicolumn{2}{|c|}{ Mode } & 75,00 & $112,00^{a}$ & 26,00 \\
\hline \multicolumn{2}{|c|}{ Std. Deviation } & 11,52630 & 15,32075 & 4,65637 \\
\hline \multicolumn{2}{|c|}{ Minimum } & 45,00 & 73,00 & 16,00 \\
\hline \multicolumn{2}{|c|}{ Maximum } & 93,00 & 132,00 & 34,00 \\
\hline \multicolumn{2}{|c|}{ Sum } & 3326,00 & 4862,00 & 1185,00 \\
\hline
\end{tabular}

a. Multiple modes exist. The smallest value is s hown

The table 3 shows that the respondents of the research were 45 students. The mean of their attitude, familiarity degree, and vocabulary mastery are 73,9, 108 and 26,3. By comparing with their mean ideal (Mi), the research data showed a higher point.

There was two statistical analysis did in this research; single and multiple regression. From the single regression analysis, it showed that the variable X1 that was the students' attitude on English loanwords in Bahasa Indonesia gave a contribution as much as $45,5 \%$ toward their English vocabulary mastery. Then, based on the distribution of frequency and tendency of data, their attitude is generally positive on English loanwords.

Table 4. Model Summary of the First Single Regression Analysis

\begin{tabular}{|l|l|r|r|r|}
\hline \multicolumn{1}{|c|}{ Model Summary } \\
\hline Model & $\mathrm{R}$ & R Square & Adjusted R Square & Std. Error of the Estimate \\
\hline 1 &, $673(\mathrm{a})$ &, 454 &, 441 & 3,482 \\
\hline
\end{tabular}

Predictors: (Constant), Attitude 
Next, the correlation score (ry) was 0.673 , the determination coefficient was 0.454 and the sig. of $\mathrm{F}$ change was 0.00 which is lower than $\alpha=0.05$. These scores can be concluded that there was a contribution of students' attitudes on English loanwords in Bahasa Indonesia toward the students' vocabulary mastery. The determination coefficient score was 0.454 or $45.4 \%$ that indicates the percentage of contribution between variable $\mathrm{X}_{1}$ toward variable $\mathrm{Y}$. It means the attitude of the IT students in IAIN Bukittinggi increased (more positive) on the using of English loanwords in Bahasa Indonesia line with their vocabulary.

The second regression analysis as seen in the following table tried to answer the second question about the contribution of a familiarity degree on English loanwords in Bahasa Indonesia toward English vocabulary mastery. It shows that this variable gave a contribution as much as $29.9 \%$ toward their English vocabulary mastery.

Table 5. Model Summary of the Second Single Regression Analysis

\section{Model Summary}

\begin{tabular}{|c|c|c|c|c|}
\hline Model & $\mathrm{R}$ & $\mathrm{R}$ Square & Adjusted R Square & Std. Error of the Estimate \\
\hline 1 &, $546(\mathrm{a})$ &, 299 &, 282 & 3,945 \\
\hline
\end{tabular}

The correlation score was 0.546 , determination coefficient was 0.299 and sig. F change was 0.00 which was lower than $\alpha=0.05$. It can be concluded that there was a contribution of students' familiarity degree on English loanwords in Bahasa Indonesia toward their vocabulary mastery. The determination coefficient score was 0.299 or $29.9 \%$ that indicated the percentage of contribution between variable $\mathrm{X}_{2}$ toward $\mathrm{Y}$.

From both single regression analysis, the percentage contribution of $\mathrm{X}_{1}$ (45.5) was higher than $\mathrm{X}_{2}$ (29.9) toward $\mathrm{Y}$. In the field of the research, it was found that some of the students involved in the research had the positive attitude on the using of English loanword, they preferred and had a tendency to use the loanword although the students did not understand what the meaning. They only used what they had heard and seen and they felt that they had understood the words. 
Based on the last analysis, the multiple regression that put $\mathrm{X}_{1}$ and $\mathrm{X}_{2}$, the students' attitude and their familiarity degree on the English loanwords in Bahasa Indonesia simultaneously. It gave the contribution to their vocabulary mastery as much as $46,8 \%$.

Table 6. Model Summary of the Multiple Regression Analysis

Model Summary

\begin{tabular}{l|r|r|r|r|}
\hline \multicolumn{1}{|c|}{ Model } & $\mathrm{R}$ & R Square & Adjusted R Square & Std. Error of the Estimate \\
\hline 1 &, $684(\mathrm{a})$ &, 468 &, 442 & 3,477 \\
\hline
\end{tabular}

Based on the results of SPSS output in table 6 , the R-value of 0.684 indicates that the variables of $\mathrm{X}_{1}$ and $\mathrm{X}_{2}$ have a strong relationship with $\mathrm{Y}$. While the value of the coefficient of determination R2 (R Square) is 0.468 or $46.8 \%$. In other words, $\mathrm{X}_{1}$ and $\mathrm{X}_{2}$ give the effect simultaneously to variable $\mathrm{Y}$ which is equal to $46.8 \%$ while the remaining $63.2 \%$ is determined by other factors, beyond the $\mathrm{X}_{1}$ and $\mathrm{X} 2$ to $\mathrm{Y}$

From the analysis above, show that the sig. $F$ change is 0.00 and it is lower than $\alpha=0.05$. The variable $X_{1}$ (students' attitude on the of English loanwords in Bahasa Indonesia) and variable X2 (familiarity degree on the English loanwords in Bahasa Indonesia) contribute significantly toward variable $Y$ (the students' English vocabulary mastery)

Then there is a strong and positive correlation which is indicated by $\mathrm{R}$ value, 0.684 . meanwhile, the determination coefficient is $0.486(48,6 \%)$ describes the contribution variable $\mathrm{X}_{1}$ (students' attitude on English loanwords in Bahasa Indonesia) and variable $\mathrm{X}_{2}$ (familiarity degree on English loanwords in Bahasa Indonesia) simultaneously toward the variable $\mathrm{Y}$, (the student's vocabulary mastery).

\section{Discussion}

The research findings indicated that there was a contribution of variables namely students' attitude on the of English loanwords in Bahasa Indonesia and students' familiarity degree on the English loanwords in Bahasa Indonesia toward 
their English vocabulary mastery either partially or simultaneously for the fifth semester student of IT at IAIN Bukittinggi in academic year 2018/2019.

From the single regression analysis, it showed that the variable $\mathrm{X}_{1}$, the students' attitude on English loanword in Bahasa Indonesia gave a contribution as much as $45,5 \%$ toward their English vocabulary mastery. Then, based on the distribution of frequency and tendency of data, their attitude generally is positive toward English loanwords. In accordance with those fact, it was found that the student who as the subject of the research had a likeness and tendency to use English loanwords in their daily life or activities. Attitude is one of the internal aspects which influence the successful of someone in learning, or the learners" attitude is generally believed play a central role in language learning. Positive attitudes to learning a language are acknowledged as influential factors in making a decision to learn and to continue learning it (Williams and Burden, 1997:25).

The second regression analysis tried to answer the second hypothesis about the contribution of a familiarity degree in English loanwords in Bahasa Indonesia. It showed that this variable gave a contribution as much as $29.9 \%$ toward their English vocabulary mastery. By having a knowledge about the adaptation of pronunciation and spelling of English loanwords into Bahasa Indonesia as well as the meaning, it becomes the foundation and prior information to increase and master their English vocabulary. Nation (2005:4) states that the existence of loanwords in the first language can become the foundation and make it easy to understand and master the source language, because most of them have the similarity in pronunciation, form, and meaning. The fact shows that many loanwords in Bahasa Indonesia have these similarities.

Based on the single regression analysis, the percentage contribution of $\mathrm{X}_{1}$ (45.5) is higher than $X_{2}$ (29.9) toward $Y$. In the field of research, it's found that some of the students who were involved in the research had the positive attitude on using of English loanword; they prefered and had a tendency to use them although they did not understand what the meaning. They just used what they had heard and seen. They felt that they had understood the words. 
In the final analysis, the multiple regression that put $X_{1}$ and $X_{2}$, students' attitude and their familiarity degree on the English loanwords in Bahasa Indonesia simultaneously. It gives the contribution to their vocabulary mastery $46,8 \%$. It shows that it is better than the previous one. The combination of both aspects can give a better result to master the English vocabulary from the loanword that exists in Bahasa Indonesia. By encouraging the learners to have the positive attitude to use the English loanword in Bahasa Indonesia, and then prepare them more with the knowledge about English loanword, theoretically, it will make them master the English vocabulary that derives from English Loanwords into Bahasa Indonesia.

The existence of English loanwords in Bahasa Indonesia promises the easiness to study the English language. Vocabulary is one of the important elements in learning language. It can be learned easier and the burden to learn vocabulary become lighter, because of the characteristics of English loanword in Bahasa Indonesia. Both English and Indonesian use roman script. Then, many of English loanwords in Bahasa Indonesia have the similarity or even the same with the origin form in English, also in the meaning and spelling.

Related to this study, most of the students are familiar and get the English loanwords unconsciously. They like, tend and proud to use all of those loanwords. So, it is important to bring this into reality. Then, there are two things that the educator needs to do: 1) they have to make the language learners aware of the existence of the English Loanword. These words are derived from English, and there is their synonym in Bahasa Indonesia. So that, the learners can return to English spelling and get easiness to translate the words into Bahasa Indonesia; 2) they have to encourage the students to have a positive attitude to use the English loanwords. A positive attitude will strengthen the students' motivation to learn more the English vocabulary from a loanword. Asuccessful learner is the one who possesses positive attitudes towards the target language.

\section{Conclusion}

The result of the research indicated that the attitude of most students of the Technology information program in IAIN Bukittinggi was positive toward the existence of English Loanwords in Bahasa Indonesia. This atitude influenced 
their ability to master the English vocabulary, especially the vocabularies that relate to loanwords, although they have got adjustment and adaptation to Bahasa Indonesian. It was shown by the result of their test.

Next, the student who had a positive attitude also got a good mark in the test in this research. The positive attitude was indicated by having pride in using them, a tendency to choose these words and easiness to return them into the right spelling and pronunciation in English. A positive attitude leads them to keep in using and learning English vocabulary.

Meanwhile, their habit to use and choose English loanword in their daily activity occurs the condition of familiarity. It was indicated by the condition in which they often use, hear and see these vocabularies. This aspect also influenced their ability to master English vocabulary from the Loanwords. The level or degree of familiarity on English loanword in Bahasa Indonesia influence their mastery of English word. The students who had a high degree in this research can return and use English vocabulary from the English Loanword in Bahasa Indonesia correctly. On the contrary, the students who had a low degree of familiarity, they only used, heard and saw the vocabulary, but they don't understand.

\section{References}

Brown, J. B., \& Williams, C. J. (1985). Gairaigo: A Latent English Vocabulary Base? Tohoku Gakuin University Review: Essays and Studies in English Eibungaku 76, 129-146.

Creswell, J.W. (2002). Educational Research: Planning, Conducting and Evaluating Quantitative and Qualitative Research. Boston: Pearson Education, Inc.

D'Anna, C. A., Zechmeister, E. B., \& Hall, J. W. (1991). Toward a Meaningful Definition of Vocabulary Size. Journal of Reading Behavior. 23.

Devianty, R. (2016). Loanword in Indonesia. Journal Vision, 9 (9) 1-8.

Ellis, R. (1999). Second Language Acquisition. Oxford: Oxford University Press. 
Fauzi, I. (2014). English Borrowing in Indonesian Newspaper. Journal on English as a Foreign Language, 4 (1) 15-28. https://doi.org/10.23971/jefl.v4i1.71

Hara, Y. (2011). The Use of Loanwords in English Vocabulary Learning. Thesis, Indiana: Ball State University.

Marzano, Robert J., and Debra J. Pickering, (1997). The Dimension of Learning, Virginia USA: ASCD Press.

Nation. I. S. P. (2001). Learning Vocabulary in Another Language. Cambridge: Cambridge University Press.

Nation. I. S. P. (2005). The Role of The First Language in Foreign Language Learning. http://www.asian-efl-journal.com.

(1987). What is Involve in Learning a Word in Teaching and Learning a Language? New Zealand, Victoria. Wellington University.

Nurweni, A., (2013). Meaning of English Loanwords in Indonesian Article of Sport. Jurnal Humaniora, 25 (2). 184-192. https://doi.org/10.22146/jh.v25i2.2361

Richards. J. C. and Richard Schmidt. (2002). Longman Dictionary of Language Teaching and Applied Linguistics. London: Pearson Education Limited.

Yoshida, M. (1978). The Acquisition of English Vocabulary by a JapaneseSpeaking Child. In E. M. Hatch (Ed.): Second Language Acquisition. New York: United States: Newbury House. 